\title{
Misdiagnosis: Incomplete Cures of Financial Regulatory Failures
}

James R. Barth, Gerard Caprio Jr., and Ross Levine*

July 25,2014

* James R. Barth: Lowder Eminent Scholar in Finance, Auburn University and Senior Finance Fellow, Milken Institute, Gerard Caprio, Jr.: William Brough Professor of Economics and Chair, Center for Development Economics, Williams College, Ross Levine: Willis H. Booth Chair in Banking and Finance, University of California, Berkeley, Senior Fellow at the Milken Institute, and Research Associate at the NBER. 


\section{Introduction}

US authorities are attempting to improve financial regulation and supervision. Within the structure of the Dodd-Frank Wall Street Reform and Consumer Protection Act (Dodd Frank) of 2010, the Treasury Department, Board of Governors of the Federal Reserve system (Federal Reserve), Securities and Exchange Commission (SEC), Federal Deposit Insurance Corporation (FDIC), and other official authorities are seeking both to enhance the stability of the financial system and the efficiency with which it allocates capital. Beyond the United States, the Financial Stability Board, the Bank for International Settlements, and other international institutions bring together regulators and supervisors from around the world to discuss and coordinate strategies for enhancing the safety and soundness of the global financial system.

In the aftermath of the global financial crisis, these attempts involve a three-step process: (1) diagnose what went wrong, (2) design regulatory and supervisory reforms that address these defects, and (3) implement the corrective reforms. Things can go awry at each step. Authorities might misdiagnose the causes of the crisis either by focusing on factors that did not actually contribute much to the crisis or by ignoring factors that did. Authorities, moreover, might correctly identify what went wrong but design the wrong remedies, such that the proposed reforms will not actually fix the problems. Furthermore, even when the diagnosis is on the mark and the reforms well designed, but the authorities might have trouble implementing the reforms as intended.

In this paper, we argue that efforts to enhance US financial regulation and supervision have faltered along each of these three dimensions. Thus, the purpose of our paper is to highlight deficiencies in the diagnosis of and policy response to the so-called global financial crisis (GFC). We focus on regulatory and supervisory reforms since 2009. We therefore ignore the immediate response of governmental authorities to the major financial system disruption in the fall of 2008. 
In particular, the US authorities misdiagnosed, or perhaps in some cases even willfully disregarded, the causes of the crisis both by overemphasizing factors that did not play decisive roles in causing the onset or the severity of the crisis and by underemphasizing factors that did. For example, policymakers and regulators stress that regulatory gaps and insufficient coordination and cooperation among different regulatory and supervisory agencies played crucial roles in precipitating the crisis. But as we document below, little to no evidence supports this claim. Similarly, many emphasize that insufficient resources and supervisory authority made it difficult for officials to identify growing risks and to contain such risks when they were detected. But as we argue below, little to no evidence supports these claims either.

Most important, the authorities provide an incomplete diagnosis of what went wrong. They focus too little on how the regulatory and supervisory apparatus repeatedly chose and maintained bad policies over many years. This crisis was not simply the result of a confluence of unforeseeable events, exacerbated by regulatory gaps, insufficient coordination among agencies, and inadequate regulatory and supervisory power and resources. At several important points in time that we document below, supervisory and regulatory authorities identified growing risks and yet did not act. By misdiagnosing the problem, it is unsurprising that reforms focus excessively on some comparatively unimportant features of regulation and supervision, and insufficiently on major deficiencies in the system.

As a result of the misdiagnosis, many of the reforms advanced by the authorities will do little to fix problems with the regulations and supervision of financial markets and institutions, and improve the safety and soundness of the US financial system. For example, the core motivation for establishing a financial stability oversight counsel was to enhance communication across agencies on systemically important financial institutions. Yet do we really believe that a primary cause of the crisis was the inability of regulators to pick up a phone to speak with their counterparts at other agencies? Indeed, an interagency body — the federal financial institutions examination council—already existed to address just this issue. It was established in March 1979! As another example, consider the Consumer Financial 
Protection Bureau (CFPB), which was established in the wake of the crisis to prevent the financial sector from abusing unsophisticated purchasers of financial products. It is difficult to be opposed to such a goal, and we are not. However, the CFPB essentially centralizes the consumer protection functions of the Federal Deposit Insurance Corporation, the Federal Reserve, and other financial regulators. To the extent that the consumer protection units within these agencies failed to do a good job, why will the CFPB do better without seriously addressing the core institutional weaknesses that produced the poor protection of consumers in the first place?

Our paper provides many other similar examples of regulatory failings. We argue that even if key elements of Dodd-Frank had been implemented a decade earlier, they would not have had much of an effect on reducing the likelihood or severity of the financial crisis. Although Dodd-Frank makes several important contributions to financial stability, it is materially incomplete. Indeed, it ignores a major, if not the major, cause of the crisis: the choice and maintenance of regulatory and supervisory practices that permitted and, in some cases encouraged, excessive risk taking by financial institutions.

Perhaps what is most disconcerting, reforms are not going well. Dodd-Frank and other related reforms by major regulatory authorities may be hurting, not helping, promote financial stability and the efficiency of capital allocation. As noted above, the United States increasingly relies on empowered regulatory and supervisory agencies — and thereby decreasingly relies on market discipline — to maintain the safety and soundness of the financial system. This means we are to an ever greater degree relying on agencies without improving the incentives, governance, and accountability of these agencies - agencies that are partially culpable for the crisis.

In addition, US reforms have intensified moral hazard. First, the authorities came to the rescue of major commercial banks, major investment banks, a large insurance company, the two home financing giants, and money market mutual funds. That is, the US authorities saved the creditors of major financial institutions, even though these institutions did not enjoy explicit government backing. And in many cases, the government had explicitly emphasized that it would not save the creditors. Second, by expanding the 
power and perimeter of regulation and supervision, private investors have fewer incentives to monitor and discipline the same, as well as a wider range of financial institutions. As officials take on more responsibility for monitoring a broader group of financial institutions, private investors will do less monitoring. As such, US authorities have dramatically increased the problem of Too Big to Fail (TBTF). They have increased it by signaling that there is still a high likelihood that they will rescue large failing institutions.

Finally, pieces of evidence raise concerns that the regulatory authorities remain under the sway of special interests. For example, Dodd-Frank requires banks to maintain on their balance sheets at least 5 percent of the loans that they are selling. Regulators, however, have allowed exemptions so broad that, according to Mark Zandi, chief economist at Moody's, this particular minimum would not have applied to 98 percent of mortgages originated in 2012. Similarly, regulators have allowed banks to record second mortgages at face value on their books, even when borrowers were delinquent on other obligations. Of course, not every decision the authorities have made has tilted in one direction. Given the performance of the regulatory and supervisory agencies in the buildup to the crisis, however, these decisions are worrisome.

The remainder of the paper proceeds as follows. The next section discusses diagnoses of what caused the financial crisis provided by influential regulatory authorities, among others. The third section explains why these diagnoses are flawed or incomplete as well as fatal shortcomings of the ongoing reforms to prevent another such crisis. The fourth section discusses the progress made to date on implementing the reforms and the problems that they themselves raise. The last section contains our conclusions. 


\section{US Regulatory Diagnosis and Response}

This section first summarizes the core components of influential diagnoses of the causes of the financial crisis and then describes the policy response by US authorities. The point is neither to provide a comprehensive list of the causes of the crisis nor to provide a comprehensive survey of the literature on what went wrong. Instead, the goal is to identify major causal factors identified by US and international authorities and discuss how this diagnosis shaped the policy response.

\subsection{A Common Diagnosis of What Went Wrong}

Influential diagnoses of the GFC often start by emphasizing the global conditions that enabled and indeed encouraged the US financial crisis. In particular, it is noted that a global savings glut and internationally integrated financial markets facilitated large capital flows into the United States. These capital inflows pushed down interest rates and boosted asset values. The expanded supply of funds also encouraged both (1) the creation of novel, poorly understood financial instruments that managed to obtain the highly valued 'AAA' credit rating, and (2) a weakening of underwriting standards that further encouraged the use of complex derivative and structured credit instruments whose risk characteristics were not fully appreciated. This situation led to a rapid deterioration in the performance of many financial institutions, reflecting deficiencies in risk management and evaluation procedures. At the same time, the profits from creating, rating, and selling highly rated securities soared. Thus, international conditions funneled large amounts of capital flows into the United States in search of financial instruments with AAA status, and the financial services industry supplied that demand through financial innovation and lower standards.

According to financial policy luminaries, the confluence of unprecedented and unforeseeable events — sometimes referred to as a 'perfect storm' - triggered a bubble in asset prices that eventually popped, causing the global financial crisis. These luminaries include former Treasury Secretary Timothy Geithner; his predecessors, Henry Paulson and Robert Rubin; the former chairman of the Federal Reserve board, Ben Bernanke; and his predecessor, Alan Greenspan; along with the former French finance 
minister and current head of the International Monetary Fund, Christine Lagarde. Reports by the US authorities and the global financial stability reports of the IMF all tell a similar story about the sources of the crisis. From this perspective, financial policymakers are now engaged in the process of redesigning the global financial system architecture to reduce the probability of future crises.

Beyond the 'international enabling environment' as a causal factor, standard diagnoses stress that US supervisory and regulatory agencies did not have sufficient resources or adequate authority over the full range of systemically important financial institutions. It was often unclear, moreover, who had supervisory authority over such institutions; insufficient legal authority and regulatory gaps often made it impossible to respond effectively as risks mounted. Diagnoses emphasize that the perimeter of supervisory oversight did not extend to 'shadow banks' and to some large securities and derivatives markets, such as the over-the-counter derivatives market, unregistered structured products, and offexchange trading platforms. Thus, to many influential policymakers and analysts, the crisis revealed deficiencies in the US supervisory system. The fragmentation of resources, information, and powers across several regulatory agencies, and insufficient collaboration and coordination, hindered transparency, accountability, and the effectiveness of the entire financial supervisory apparatus. As a larger proportion of financial activities and transactions over time was being conducted in financial conglomerates, weak inter-agency communication and insufficient consolidated supervision thwarted efforts to monitor risk in banks, broker-dealers, insurers, and other financial institutions.

In light of this diagnosis of the causes of the crisis, the US response - as embodied in DoddFrank - is unsurprising: it empowers supervisory and regulatory agencies to oversee all systemically important financial institutions and charges them to use this power to more rigorously monitor and limit risks. 


\subsection{The Dodd-Frank Wall Street Reform and Consumer Protection Act}

In an important sense, Dodd-Frank is the typical response to a financial crisis. It is based on an all-too-common diagnosis that the regulatory authorities are largely taken by surprise by crises and, in each case, lack sufficient powers to curtail, if not prevent, adverse effects. At least in terms of length, however, Dodd-Frank goes well beyond the usual response; at 2,319 pages, it sets a new record in terms of length, far exceeding the combined length of all major pieces of federal financial legislation over the past century. Indeed, the 1913 law establishing the Federal Reserve was only 31 pages long. Even the more recent Gramm-Leach-Bliley Act of 1999, which prohibits commercial firms from owning banks and vice versa, was only 145 pages long.

Dodd-Frank consists of 16 titles and more than a thousand sections. The various financial regulators have been spending more than four years reading, interpreting, and writing hundreds of new rules to implement it. Moreover, of the 330 rule-making provisions, 208 do not even impose any deadlines for issuing the rules. The law also mandates more than 60 studies and a hundred congressional reports.

We now explain several components of Dodd-Frank that are meant to be implemented in such a way as to prevent future financial crises. As will become clear, the law leaves considerable discretion to the regulators in implementing it, just as with past financial legislation. While this may be fine, what is not so fine is the continued practice of allowing regulators to exercise such discretion without sufficient accountability to the public, especially given their past performance record.

\subsubsection{Financial Stability Oversight Council}

Dodd-Frank created the Financial Stability Oversight Council (FSOC) to identify, monitor, and address any systemic risk posed by large, complex, interconnected financial firms, including both banks and non-bank financial firms. The latter firms, including hedge funds, private equity firms, investment banks, and mutual funds, are part of the 'shadow banking' system. Such firms may become so large and 
interconnected that their failures could disrupt the entire financial system. Gorton and Metrick (2010) make the point that these types of firms perform the same functions of banks and are as systemically interconnected as banks, but unlike banks, these shadow banks are virtually unregulated.

The FSOC is also authorized to make recommendations to the Federal Reserve on prudential standards for systemic risk firms, including leverage and risk-based capital standards, liquidity requirements, and resolution plans. In particular, financial firms with total assets of $\$ 50$ billion or more are required to provide information on their financial condition and systems for monitoring and controlling for various risks, as well as the extent to which they could, under adverse circumstances, potentially affect the overall financial stability of the country. The individuals overseeing these tasks are nine voting members, including the federal financial regulators and one independent member with insurance expertise, as well as five nonvoting members, including three state regulators. The secretary of the treasury serves as chairperson.

To support the FSOC, a new Office of Financial Research (OFR) is established within the Treasury Department, with the director appointed by the president, subject to confirmation by the Senate. Its responsibilities include promoting best practices for financial risk management, monitoring and reporting changes in systemic risk, and evaluating and reporting on stress tests for banks. There are two types of stress tests. First, the Federal Reserve must conduct annual supervisory stress tests of banks with $\$ 50$ billion or more in total assets and nonbank financial companies designated by the FSOC, of which three were so designated in early 2014. Second, financial companies with more than $\$ 10$ billion in total assets must conduct annual stress tests, and banks with $\$ 50$ billion or more in total assets and nonbank financial companies designated by FSOC must also conduct their own semiannual stress tests. The results of the Federal Reserve's annual tests were released in early March 2014 for a total of 30 banks with \$50 billion or more in total assets. 


\subsubsection{Consumer Financial Protection Bureau}

The Consumer Financial Protection Bureau (CFPB) was created to regulate all consumer financial products. The CFPB takes over the consumer protection functions and rulemaking from all existing financial federal regulators. Since the crisis saw a number of abusive practices, it is clear that consumer protection is a real and legitimate goal of regulation. The annual budget for the new agency is scheduled to increase from 10 percent to 12 percent of the Federal Reserve's budget as it ramps up to its operations to full force. This is a big enough budget to support a substantial amount of discretion that the CFPB can exercise in regulating consumer financial products.

The CFPB has vast powers. It may enforce federal laws intended to ensure fair, equitable, and nondiscriminatory access to credit for both individuals and communities. The CFPB may impose and keep fines, or distribute them to injured consumers. It is to conduct compliance exams for large banks (with more than $\$ 10$ billion in assets) and covered non-banks, with the exams to be coordinated with the FDIC, Federal Reserve, and state bank regulators. The CFPB may not 'establish a usury limit' but may be able to indirectly regulate interest rates by finding a rate to be 'unfair'.

The CFPB has issued several new rules for the mortgage market, including the Ability-to-Repay and Qualified Mortgage (QM) rule, which requires that creditors make a reasonable, good-faith determination at the time of consummation that a consumer has a reasonable ability to repay a mortgage. Certain mortgages, called QMs, meeting specific criteria set forth in the rule, are entitled to a presumption of compliance with the ability-to-repay requirements. The CFPB rules also generally require that a consumer's backend debt-to-income (DTI) ratio may not exceed 43 percent for a QM, with some exceptions. 


\subsubsection{Volcker Rule}

The Volcker Rule prohibits banks from engaging in proprietary trading, which occurs when a firm trades with its own funds, not its clients, for its own benefit, not theirs. Drawing a fine line between these two types of activities is clearly no easy task. The so-called 'Volcker Rule,' named after the former Federal Reserve chairman who proposed it, does provide for certain exemptions, such as activities related to market making and the underwriting of certain US Treasury and agency securities and other foreign government securities. A bank may make and retain an investment in a hedge fund or private equity fund that the bank organizes and offers, subject to a de minimis investment.

\subsubsection{Orderly Liquidation Authority}

Dodd-Frank has created a new mechanism for the orderly liquidation of large, complex, interconnected significant financial companies. The goal is to once and for all resolve the TBTF problem so as to eliminate any future taxpayer bailouts. The law specifically excludes Fannie Mae and Freddie Mac. Instead, the fate of these two systemically important financial firms is to be determined by a recommendation of the secretary of treasury, based on a study the Treasury Department is required to conduct regarding options for ending their conservatorship while minimizing the costs to taxpayers.

An orderly liquidation fund is established within the Treasury Department. It is managed and to be used by the FDIC to liquidate failing systemically significant financial companies. It is not pre-funded, so the funds to cover liquidation costs are to be borrowed from the Treasury and the debt repaid from the liquidated assets. In addition, required risk-based assessments are to be levied on banks with total consolidated assets of $\$ 50$ billion or more, and on systemically significant nonbank financial companies supervised by the Federal Reserve. When a big financial company is failing, the secretary of the treasury, in consultation with the president, now has the ultimate authority to recommend the appointment of the FDIC as receiver. This appointment can proceed with the agreement of the Federal Reserve. The new 
procedure is meant for emergencies only, with most large financial companies still expected to be resolved through the normal court bankruptcy process.

It is certainly time to design and implement an improved orderly liquidation process, as well as one that would no longer require taxpayers to bear any of the liquidation costs of failed financial firms. To the extent that bank creditors do not find the formal liquidation process clear and credible, they might correctly assume that the government will bail them out if the bank falters. Thus, without a sound orderly liquidation process, creditors might impose less market discipline, with adverse effects on bank risk taking. Thus, to assist the regulatory authorities in designing a sound ex post resolution process as a mechanism to improve ex ante market discipline, systemically significant financial institutions must submit 'funeral' plans (i.e., plans for how a company should be wound down and eventually disposed of in the event it becomes insolvent) to the regulatory authorities—and, once approved, to the public.

\section{Incomplete Diagnoses and Cures}

Three dimensions characterize the incomplete diagnosis of and response to the crisis. ${ }^{1}$ First, some components of the diagnosis are misguided in that they focus on factors that did not play a decisive role in precipitating the crisis. Second, several major reforms are unlikely to improve the functioning of the financial system. In other words, even if key elements of Dodd-Frank had been implemented a decade earlier, they would not have had much of a preventative effect. Third, US and international authorities misdiagnosed the crisis by giving too little attention to other contributing factors. By not rigorously dissecting the regulatory and supervisory failures, reform efforts have been materially incomplete. In the remainder of this section, we discuss each of these shortcomings in the diagnosis and response to the crisis.

\footnotetext{
${ }^{1}$ This section draws heavily from Barth et al. (2012).
} 
3.1. Did regulatory, information, and coordinate gaps play decisive roles?

It seems that the underlying motivation for establishing the Financial Stability Oversight Council is to provide an improved opportunity for financial regulators with somewhat different supervisory responsibilities to communicate with one another. Yet it's hard to believe that regulation was ineffective in terms of crisis prevention because the regulators didn't all belong to the same council or couldn't pick up a phone to speak with their counterparts at other agencies. After all, an interagency body already existed: the Federal Financial Institutions Examination Council (FFIEC), having been established in March 1979. The FFIEC consists of the Federal Reserve, the FDIC, the National Credit Union Administration (NCUA), the Office of the Comptroller of the Currency (OCC), and, the Office of Thrift Supervision (OTS) before it was merged into the OCC. Despite the existence of the FFIEC, two financial crises - the savings and loan (S\&L) crisis as well as the most recent crisis - took place under its watch. The experience gained over time by members working together for a common purpose based on a common approach to detecting problems did not appear to be of much help since the second crisis was far more severe and widespread than the first. It is therefore not clear that yet another council will be much of an improvement with respect to preventing another financial crisis. Meanwhile, the secretary of the Treasury and chairman of the Federal Reserve board have long had a practice of regular meetings, often weekly, supported by numerous contacts at many levels of their respective staff.

In addition, the rationale for the Financial Stability Oversight Council seems to rest on the assumption that the crisis was characterized by activities that were hard to detect or that fell between the jurisdictions of different agencies. This argument holds a bit of truth, as AIG was a savings-and-loan holding company supervised by the now-abolished OTS, as well as a state regulator, with OTS one of the weakest links in the pre-crisis regulatory chain. But the Federal Reserve also had jurisdiction. It just wasn't paying attention or, if it was, it didn't act. After all, it was the Federal Reserve's decision to allow banks to enjoy lower required capital ratios when they purchased credit default swaps from firms like AIG that gave those firms and others the ability to help blow up the financial system. The Federal Reserve did this without any due diligence over the providers of this form of insurance and did not protest 
that it needed the ability to oversee them before the crisis. Yet it still could have stopped allowing banks to enjoy lower capital ratios with credit default swaps, as their use and associated risk were skyrocketing.

There just is not much factual evidence that the crisis was driven by a failure to communicate or an inability to detect problems due to gaps between regulators. Regulators clearly knew about activities that precipitated the financial crisis. Consider, for example, that real estate assets at all FDIC-insured depository institutions accounted for nearly half of their total assets, or roughly \$7 trillion, in 2007. This huge amount of outstanding real estate loans was due to double-digit growth rates during the 2001-2007 period. At the same time, housing prices were also growing at double-digit rates in many parts of the country. It is reasonable to presume that regulators were either well aware of these particular facts or should have been aware of them — which is important because all financial institutions heavily involved in real estate would suffer if real estate prices were to collapse. Moreover, as argued in Barth et al. $(2012,5)$, regulators in Iceland, Ireland, and the UK similarly failed to take action when faced with clear signs of excessive risk taking and despite the presence of a single financial regulator for the entire financial system.

US regulators also knew well that a large portion of all real estate assets had been securitized or were being held off-balance sheet, waiting to be securitized. So it is also reasonable to assume that regulators would have or should have been fully aware of the potential fallout from a collapse in real estate prices. If they couldn't focus on a widely held asset class like home mortgages and then think in terms of systemic fallout rather than damage to individual depository institutions, then putting these people together on a new council is not enough, in our view, to change the decision-making process. Regulators must be charged with creating a better decision-making process to prevent or, at the very least, lessen the likelihood and severity of financial crises, and they must be accountable for seeing that the process goes into effect. And while they are welcome to engage in self-assessment, taxpayers should want their performance to be evaluated on an ongoing basis by an independent group of financial experts reporting to and therefore accountable to the public. There are many checks and balances in our society, 
but as of yet, not a truly meaningful checks and balance for our unelected, unaccountable financial regulators.

\subsection{Would Dodd-Frank have made much of a difference?}

At first glance, the FSOC might seem like a good idea, to the extent that the individual regulators previously failed to devote enough attention to systemic risk because each was focused too narrowly on its own segment of the financial system. Dodd-Frank now mandates that financial regulators meet and act as a group so as to devote far more attention to systemic risk and impose stricter prudential standards on those financial firms giving rise to systemic risk. The FSOC will in theory ensure that this happens by adding an additional layer of oversight above and beyond the individual regulatory agencies themselves. Yet the FSOC membership consists of nearly all the same regulatory agencies that were in charge prior to the crisis and that not only failed to prevent the crisis but also actually contributed to it (Barth et al., 2012, 4).

The law is silent as to how to measure systemic risk and therefore how the FSOC is to fulfill this most important duty. The exact standards are left to the discretion of the Federal Reserve. Of course, as has been the case in the past with reform legislation, the Federal Reserve remains unaccountable for whatever happens based on the standards it sets. ${ }^{2}$ The Office of Financial Research, moreover, is still another layer of bureaucracy charged to perform the same types of activities that have always been an ongoing responsibility of the financial regulatory authorities. After all, the OFR is headed by a political appointee and located within the treasury department, not within an independent agency, and these features make it more vulnerable to political pressures. Furthermore, it is not clear what happens when differences in opinion arise between OFR and the various financial regulators.

Despite Dodd-Frank's laudable goal of empowering regulatory authorities to control systemically important nonbank financial institutions, there are many questions about whether this will fix the root

\footnotetext{
${ }^{2}$ The requirement to testify before Congress should not be confused with accountability, as the Federal Reserve has an immense information and skill advantage in that exchange.
} 
causes of the regulatory failures that fostered the most recent crisis. For example, the spectacular growth of the shadow banking system from the 1980s through the crisis and beyond has not been a secret. It involved tens of trillions of dollars, more than the size of the entire banking industry. What were the systemic, institutional failings in the regulatory apparatus that allowed this to happen? Have those defects been addressed by Dodd-Frank? We don't think so because a system based on imposing more stringent requirements on banks not only encourages the growth in shadow banking but also increases the incentive for banks to move risky assets into off-balance sheet entities. In addition, it is unclear which circumstances or factors actually trigger a systemic designation by the FSOC to nonbank financial firms, and how it would proceed in a timely manner to address looming problems. It is important to remember that regulators have historically focused rather narrowly on their own specific areas of oversight. And their focus has been on institutions rather than financial instruments, such as credit default swaps and repurchase agreements, despite the potential for the latter to create problems in financial markets. So it may be a stretch to believe that the FSOC will stimulate group-think to the point that it will focus on changes in the composition of the financial system and the accompanying changes in systemic risk. Recall that the Federal Reserve was established to deal with systemic risk. When it failed to do so in the 1930s, it received backup support in the form of the FDIC. This time around, it is receiving backup support in the form of the FSOC. What will happen when the FSOC fails to prevent another financial crisis? And will the OFR now accomplish what all the other regulators collectively failed to accomplish in the past? We think not.

Turning to the Consumer Financial Protection Bureau, its director is a regulatory czar over consumer financial products. Although the FSOC may issue a 'stay' of a CFPB rule, this will require a two-thirds vote and the rule must endanger the stability of the entire financial system. We worry that this unprecedented amount of power given to a single individual could stifle financial innovation or otherwise lead to unintended and costly consequences for consumers. For example, will at some point a director be appointed who believes in concealing information from the public and mainly serves as a pawn of the banks? Or one who believes in suppressing products that genuinely help consumers manage the risks that 
they face? In other words, the post-crisis pattern continues - another unelected, unaccountable regulator has been created. Congress alone clearly does not have the expertise to assess what is being done, and its exposure to lobbying efforts makes us less than sanguine about the positive results to be achieved by this new regulator.

The CFPB takes over the consumer protection functions and rulemaking from OCC, OTS, FDIC, Federal Reserve, NCUA, Housing and Urban Development (HUD), and the Federal Trade Commission (FTC). Apparently, since these regulators failed to do a good job, their responsibilities for consumer financial products and the associated employees are transferred to a new regulatory agency. Why will CFPB work better? We don't think it does much to addresses the core institutional weaknesses that produced the poor protection of many consumers.

Even the CFPB's most basic goals are quite vague, magnifying its discretionary powers. The important point, however, is whether this discretion will be used wisely. However, how all these things are to done in an objective and defensible manner is not explained. Again, the discretion is vast, but the accountability is virtually nonexistent.

A new definition of 'abusive' practice is added in the law: one that 'materially interferes with the ability of a consumer to understand a term or condition of a consumer financial product or service; or takes unreasonable advantage of (A) a lack of understanding on the part of the consumer of the material risks, costs, or conditions of the product or service; (B) the inability of the consumer to protect the interests of the consumer in selecting or using a consumer financial product or service; or (C) the reasonable reliance by the consumer on a covered person to act in the interests of the consumer'. After reading this, is it clear to you how the CFPB will go about identifying those practices that are abusive and those that are not? We didn't think so, but don't worry. Fortunately, due to the extraordinary amount of discretion given to the CFPB, it will now ensure that financial firms will only provide those products and services to people who fully understand that they really want them.

The bottom line is that the creation of this new regulator fails to address the key weaknesses identified earlier. Apparently the logic of taking consumer regulation out of the Federal Reserve was the 
accepted view that within a central bank, consumer protection is 'third fiddle' to monetary policy and regulation, and perhaps because at least some realized that the banks had more influence within the Federal Reserve than did American consumers. For whatever reason, the Federal Reserve had widespread consumer financial and prudential regulatory powers and did not use them to prevent abuses. The likelihood and severity of another crisis will not be reduced until there is some likelihood that the Federal Reserve will to a far greater degree than it has in the past regulate in the public interest.

When it comes to proprietary trading by banks, or the Volcker Rule, policymakers and regulators have not provided evidence that such trading was a material cause of the most recent financial crisis. Furthermore, the long process of finalizing the Volcker rule indicates how difficult it is for the regulatory authorities to define proprietary trading as something observationally distinct from trading to hedge bank risk. Furthermore, the complexity of the law creates uncertainly for banks as to when violations will be deemed to have occurred. The ruling might, moreover, lead some banks to move their proprietary trading activities overseas, and banks in less restrictive countries may gain a competitive edge. Furthermore, systemically important non-bank financial companies are not covered by these restrictions, even though they compete with banks. Our point here is not to argue that the Volcker Rule will increase financial system fragility. The point is that while it is a central feature of Dodd-Frank, there is not much evidence that if it had been in existence in 2000, it would have materially enhanced financial system stability.

A major purpose of Dodd-Frank is to eliminate the TBTF problem though the orderly liquidation authority. The traditional liquidation arrangement has worked fairly well for small banks over the years, but it has been a dismal failure when it comes to big banks. Interestingly, as some banks grew enormously over time, the government simply stood idly by and watched them grow. In some cases, the government even facilitated the growth of already big banks. When several of them were at or near insolvency during the recent crisis, the government chose to bail them out. These banks were deemed TBTF. Having let them grow so large, the government could only claim it had no other choice but to rescue them.

Recall that when the federal deposit insurance funds for savings and loans, and banks were depleted in the past there were no funds initially forthcoming from either Congress or the Treasury 
Department and, as a result, regulators had to rely on other inferior methods to deal with insolvent institutions. Should we expect that the Treasury will now be ready and willing to loan money to the FDIC right away to liquidate TBTF firms if they become deeply troubled in the years ahead? Or might the Treasury resist the FDIC's attempt to close big banks in order to be spared the political embarrassment and financial cost? This is not an imaginary possibility because governments around the world have sought to postpone the recognition of losses, and in general, the lower the degree of checks and balances in government, the longer the charade and severity of problems can continue.

Again, lots of discretion is granted to regulators, but without any meaningful public accountability. For instance, without both clear guidelines about when liquidation will occur and a clear, credible commitment that the government will actually follow the guidelines, private investors will continue to treat some institutions as TBTF and hence not monitor their risk very rigorously. Why should it? The government may still support such a financial institution if the institution is insolvent. Thus, the vagueness of the policy undermines its effectiveness. Furthermore, since the secretary of the Treasury has the ultimate authority to recommend the orderly liquidation of a large financial institution, this may inject political considerations into the decision-making process. Furthermore, in a recent IMF report, Global Financial Stability Report 2014, it is estimated that the subsidies in 2013 for big banks amounted to at least 15 or so basis points in the United States. It is further reported that despite the enactment of DoddFrank, the expected value of government guarantees for a distressed big bank are higher than the precrisis level.

Of course, it is important to distinguish between establishing a new resolution procedure to address the issue of systematically significant financial firms and regulators actually following through in times of crisis in a fair and equitable manner to dispose of such firms when they become insolvent. Consider the following reality check. As of Q1 2014, five big banks (JPMorgan Chase Bank, Bank of America, Citibank, Wells Fargo Bank, and US Bank) accounted for 53 percent of the $\$ 16.7$ trillion in total banking assets. Are the Federal Reserve regulatory authorities, in conjunction with the Treasury Department, really prepared to seize and then liquidate a single one of these big banks, yet alone more 
than one of them, should conditions dictate such action? In view of their past behavior, we think not, at least not without oversight by a group other than the regulators themselves. ${ }^{3}$

The situation is even more complicated when one considers the biggest banks in the world. As of Q1 2014, there were 24 banks headquartered in 10 different countries with $\$ 1$ trillion or more in total assets. Four of these were US banks. Most of these banks are actively engaged in global activities, which would most likely inject political considerations into their liquidation. Dodd-Frank simply requires that a study be undertaken regarding international coordination and the resolution of systematically significant financial institutions. Although some progress has been made in this regard, this is still a gaping hole in addressing the TBTF issue.

Another issue related to TBTF arises from the fact that Dodd-Frank now requires that swaps be cleared through a clearinghouse and those transactions be executed on a centralized exchange. Such an exchange certainly does help reduce opacity in the over-the-counter (OTC) derivatives market and thus enables everyone to better assess counterparty risk. This facilitates both the regulatory oversight of this market and the discipline exerted on the market by its participants so as to be better able to contain systemic risk. However, a clearinghouse and a central exchange themselves may become TBTF, which will require that they be adequately supervised and regulated.

\subsection{The Ignored Contributing Factors: Poor Regulatory and Supervisory Decisions}

In this subsection, we provide a few examples to illustrate that insufficient supervisory resources, inadequate regulatory authority, and gaps in the regulatory and supervisory net were not the only—and probably not the major-precipitating factors of the crisis. ${ }^{4}$ By incompletely diagnosing the causes of the crisis, past and existing authorities have focused too much on the power, resources, and reach of regulatory and supervisory authorities, and too little on the systematically poor choices made of the authorities.

\footnotetext{
${ }^{3}$ See also the examples in Wilmarth (2013) regarding the failure of the Federal Reserve and the OCC to oversee Citibank effectively.

${ }^{4}$ Much of the discussion in subsections 3.3.1-3.3.4 relies heavily on Levine (2010).
} 
The examples that we give are not new. Besides noting that we have used them before (Barth et al., 2012), we also emphasize that we learned of these cases by reading through documents prepared by US regulatory agencies, their independent review departments, press reports, and others. Thus, an essential part of our message is that the regulatory authorities themselves knew of these deficiencies in the functioning of the financial policy apparatus and did not change their policies as problems arose. This is the major misdiagnosis: regulatory agencies knew that their policies were not working well and yet did not change them.

\subsubsection{Credit Default Swaps and Bank Capital}

The standard diagnosis of the financial crisis emphasizes the role of new, complex financial instruments: financiers used such newly designed products to boost profits, with the systemic risks of these financial innovations largely unknown. But is this diagnosis accurate and complete? Consider credit default swaps and their link to bank capital.

A credit default swap (CDS) is an insurance-like contract written on the performance of a security or bundle of securities. For example, purchaser A pays a fee for a CDS from issuer B on security C. If security $\mathrm{C}$ has a predefined 'credit-related event', such as missing an interest payment, receiving a credit downgrade, or filing for bankruptcy, then issuer B pays purchaser A.

The explosive growth of CDSs was abetted by the Federal Reserve's 1996 decision permitting banks to use CDSs to reduce the amount of capital required to be held against potential losses on risk assets. Specifically, the Federal Reserve treated the securities guaranteed by a seller of CDSs as if they had the same risk level of that seller of the CDS. For example, a bank purchasing full CDS protection from American International Group (AIG) on collateralized debt obligations (CDOs) linked to subprime loans would have those CDOs treated as AAA securities for capital regulatory purposes because AIG had an AAA rating from a an SEC-approved credit rating agency. 
Allowing banks to reduce capital through the purchase of CDSs, however, created material systemic risks. Some bank counterparties developed massive exposures to CDS risk. AIG had a notional exposure of about $\$ 500$ billion to CDSs (and related derivatives) in 2007 , while having a capital base of about $\$ 100$ billion to cover all its traditional insurance activities, as well as its financial derivatives business.

The Federal Reserve was aware of such problems. Tett (2009, pp. 157-163) recounts how Timothy Geithner, then president of the New York Federal Reserve bank, became concerned in 2004 about the lack of information on CDSs and the growing counterparty risk facing banks. Barth et al. (2009, pp. 184-193) demonstrates through the use of internal Federal Reserve documents that the Federal Reserve knew by 2004 of the growing problems associated with subprime mortgage-related assets, on which many CDSs were written. And Lewis (2009) and McDonald (2009) illustrate the Federal Reserve's awareness by 2006 of AIG's growing fragility and the corresponding exposure of banks to CDS counterparty risk.

The key question is, why did the Federal Reserve not adjust its policies with respect to bank capital and CDSs as it learned of the growing fragility of the banking system due to the mushrooming use of increasingly suspect CDSs. Why didn't the Federal Reserve prohibit banks from reducing regulatory capital via CDSs until the Federal Reserve had confidence in the financial viability of the institutions selling CDSs to banks? The Federal Reserve's decision to maintain its regulatory stance toward CDSs was neither a failure of information nor a shortage of regulatory power. 


\subsubsection{Securities and Exchange Commission and Consolidated Supervised Entities}

Although senior SEC officials repeatedly asserted that they were adequately supervising the five largest US investment banks, with over \$5 trillion of assets, and although the SEC often claimed that the banks were safe and sound, they either failed or received government assistance in 2008. Three days after the SEC chairman expressed confidence in its financial soundness, the Federal Reserve provided an emergency $\$ 25$ billion loan to Bear Stearns. A few days later, with additional financial assistance from the Federal Reserve, Bear Stearns merged with the bank JP Morgan Chase \& Co. Six months later, Lehman Brothers went bankrupt, and shortly thereafter, at the brink of insolvency, Merrill Lynch merged with Bank of America. In the autumn of 2008, Goldman Sachs and Morgan Stanley were 'pressured' into becoming bank holding companies by the Federal Reserve and arguably rescued from failure through an assortment of public programs.

These failures were not the unforeseeable events suggested by many government officials. Rather, in our view, the supervisory and regulatory system encouraged excessive risk taking in the years leading up to the crisis. Consider three interrelated SEC decisions regarding the regulation of investment banks. First, the SEC in 2004 exempted the five largest investment banks from the net capital rule, which was a 1975 rule for computing minimum capital standards at broker-dealers. Leverage ratios soared from their 2004 levels, as the investment bank's models indicated that they had sufficient capital cushions, given their risk. Second, in a related, coordinated 2004 policy change, the SEC enacted a rule that induced the five investment banks to become 'consolidated supervised entities' (CSEs): The SEC would oversee the entire financial firm. Specifically, the SEC now had responsibility for supervising the holding company, broker-dealer subsidiaries, and all other subsidiaries on a consolidated basis. Given the size and complexity of these financial conglomerates, overseeing the CSEs was a systemically important and difficult responsibility. Third, the SEC neutered its ability to conduct consolidated supervision of the major investment banks. The SEC had only seven people to examine the parent companies of the investment banks. After 2005, the SEC even eliminated the risk management office and failed to 
complete a single inspection of a major investment bank in the year and a half before the collapse of those banks (Labaton, 2008).

Thus, the SEC reduced capital requirements, told investors and the public that it was effectively supervising these mammoth financial institutions and that they were safe to invest in, while simultaneously not devoting the resources necessarily for assessing and curtailing excessive risk. The SEC's decisions created enormous latitude and incentives for investment banks to increase risk, and they did. The SEC became willfully blind to excessive risk taking.

It is illuminating to note that the SEC's own inspector general stressed that the SEC identified the core problems, had the legal authority to address growing fragilities in investment banks, and did not respond in an appropriate manner. It was not a problem of information; it was not regulatory gaps; it was not an insufficient supervisory perimeter; and it was not inadequate legal authority. These observations suggest that granting the authorities greater power over a wider array of financial institutions and markets will not address core contributors to the crisis: the creation and maintenance of poor regulatory and supervisory policies.

\subsubsection{Federal Deposit Insurance Corporation}

The FDIC provides another example of regulatory and supervisory failure that does not reflect a lack of information, insufficient power, or unclear responsibilities. That is, the FDIC provides another example of the misdiagnosis of the causes of the crisis. The FDIC regulates and supervises deposit-taking banks, which had assets of over $\$ 13$ trillion in 2008 . So it was then and is now centrally important to the stability of the US financial system.

Not only did the FDIC have the authority to take corrective action to address banks that it decided were weak, it was required by law to take prompt and corrective action when it discovered problems with the banks that it insures. Indeed, the 1991 FDIC Improvement Act mandates that the FDIC must respond promptly to correct when it discovers weaknesses in banks. In particular, whenever a bank's capital falls 
below predetermined levels or if the bank shows others signs of weakness, this law requires the FDIC to act promptly to take corrective action.

However, it did not do so. Based on its own self-assessment, the FDIC found that in about 80 percent of the banks that failed, the FDIC inspectors had identified exactly the problems that would ultimately cause the failures years before the actual failures. But in about $95 \%$ of the cases where the FDIC found areas of material bank weakness, it did not act promptly and correctively. ${ }^{5}$ The FDIC's own Material Loss Reviews of banks that failed are replete with comments such as '... [f]or the most part, examiners identified the management deficiencies and brought their concerns to bank management', but 'many of the deficient management practices continued until the bank's failure'.

The FDIC's post mortems suggest that bank failures were not due to a lack of information, excessively complex banking operations, strange financial instruments, a lack of resources, too little legal authority, or regulatory gaps. Rather, the FDIC chose not act. Just as the Federal Reserve chose not address the reduction in bank capital or increased leverage due to banks purchases of credit default swaps and just as the SEC chose not to devote the resources to actually supervising the major investment banks on a consolidated basis as it told Congress and private investors that it was doing just that, the FDIC chose not to act promptly and correctly. It is this type of systemic deficiency in the regulation and supervision of financial institutions that has gone misdiagnosed and largely unaddressed by US authorities.

\subsubsection{The Role of Basel}

US authorities were hardly unique in not fulfilling their responsibilities. In addition to concerns about the diagnosis of the US crisis and the poor performance of US regulatory authorities is the broader concern that although it might provide comfort to some that recent decades have seen a convergence in approaches to regulation, a cause for grave concern is that this approach contributed to, rather than

\footnotetext{
${ }^{5}$ These statistics come from the Material Loss Reviews that are provided online by the FDIC. A discussion and summary of this information is in Barth et al. (2012, pp. 111-115).
} 
reduced, the risk of a crisis by encouraging banks to concentrate their risks and by distracting regulators from the work that should have been commanding their attention.

Under the umbrella of the Basel Committee and the Financial Stability Board (FSB), ${ }^{6}$ the regulatory framework in banking has become ever more complex, in part as a result of a reliance on risk weighting for the purpose of setting capital ratios. Complexity has been decried by Haldane and Madouros (2012), who cite a literature that argues for simplicity in decision making in the face of uncertainty. And many, especially after the global financial crisis, have noted that banks were able to use their internal risk models to reduce required capital ratios. Yet the Basel Committee's response to these complaints has been to form a committee to study simplicity (without abandoning risk weights) and to try to reduce the variation in risk models across banks (Caprio, 2013).

Unfortunately, the problem with risk weighting that has received too little attention is that risk is endogenous, and among the factors that influence it is the regulatory framework. In fact, assigning risk weights to different assets illustrates a 'sort of' fallacy of composition because its simple premise fails at the micro level. A single bank seems safer — suggesting the need to hold less capital — to the extent that it holds safer assets. As appealing as that idea is, it is not true, because the banking system as a whole could become riskier holding such assets. In the extreme case, the entire system might hold a highly concentrated portfolio ('low-risk' Greek debt or 'highly rated' CDOs), in which case it is more exposed to a catastrophic loss than otherwise would be the case. For the banking system as a whole, any system that encourages banks to hold a similar portfolio, whether due to the same set of risk weights or to models that yield similar assessments of risk, increases systemic fragility. Danielsson et al. (2001) noted that in a crisis this approach can encourage a run for the exit, and Caprio (2013) argues that it does its damage in good times, when banks' exposures are becoming more concentrated. Although some believe that this problem can be fixed with better inputs (e.g., more accurate credit ratings), that view ignores the fact that

\footnotetext{
${ }^{6}$ The FSB evolved from the Financial Stability Forum, a group, formed in 1999, of the finance ministries and central banks of G-10 countries, plus representatives of international financial institutions (e.g., the World Bank and IMF, the ECB, the Basel Committee on Banking Supervisions, and selected other international standards bodies). FSB membership was extended to a broader group of countries, namely the G-20 (http://www.financialstabilityboard.org/members/links.htm).
} 
the application of models or risk weights affects the incentives and behavior in banks. Indeed, it is ironic to hear those who espouse the Basel approach blame the ratings industry, as Basel, along with other regulations mandating or encouraging the holding of highly rated securities, created the demand for the latter and contributed to the explosion of earnings in the ratings industry, which in turn distorted incentives there. And disturbingly, countries like the US and the UK that were held up as regulatory models for others were at the epicenter of the crisis.

Two further aspects of complexity in regulation are important. First, complexity is a bigger burden for smaller banks, as larger banks are more easily able to spread the cost of hiring staff skilled in modeling and in regulatory compliance. At a time when many are concerned about excessive size and concentration in banking, a regulatory approach that encourages such a trend seems curious, and may reflect the extent to which regulators are responsive to or biased in favor of the big banks. Second, the more complex the regulations, the more difficult it is to hold regulators accountable. Complex regulations offer banks ample opportunities to evade their intent, and to do so beyond the oversight of all but the most informed experts. As suggested above, a regulatory system without accountability will dependably work in favor of the industry, rather than the public interest. Tellingly, the Basel Core Principles focus on the revelation of information to the supervisory agency, and not on the information that supervisors need to disclose to the public. But without information on what supervisors know, when they come to know it, and what they recommend on the basis of that information, real accountability is not likely to materialize. All of these drawbacks to an extremely complex approach to regulation suggest a scrapping of the Basel approach and a complete revisiting of regulation, with a focus on the incentives created by the regulatory framework. Given the drawbacks of risk weighting, their abandonment and a reliance on a simple leverage requirement seems desirable. 


\subsection{An Inadequate Diagnosis and Response}

Along some key dimensions, the diagnosis of and response to the crisis was incomplete and misguided. For example, influential assessments of the causes of the crisis repeatedly emphasize regulatory gaps and too little coordination and cooperation among different regulatory and supervisory agencies. Without disagreeing that the byzantine organization of US financial regulation is outdated and inefficient, we note that very little evidence has been produced to support the view that regulatory gaps were a decisive contributing factor to the crisis. As another example of deficient diagnosis and response to the crisis, this section argued that the major components of Dodd-Frank would not have significantly increased the probability of avoiding the crisis, or its severity, had it been implemented a decade earlier. Although Dodd-Frank makes several important contributions to financial stability, it is materially incomplete; it ignores a major, if not the major, cause of the crisis.

The authorities have focused too little on the systematically poor decisions of regulatory and supervisory agencies over the many years leading up to the crisis, not to mention similar poor decisions in previous crises. This crisis was not simply the result of unforeseeable events, exacerbated by regulatory gaps, insufficient coordination among agencies, and inadequate regulatory and supervisory power and resources. Along far too many dimensions, supervisory and regulatory authorities had the information to identify growing risks and the authority to address those problems. They chose not to act in a timely and appropriate manner. By not highlighting this contributing factor to the crisis, the response has not satisfactorily examined and addressed the sources of these regulatory and supervisory failures. 


\section{Progress}

\subsection{Have Reforms Intensified or Mitigated TBTF?}

The US response to the crisis has materially intensified moral hazard. The authorities came to the rescue of major banks, major investment banks, a large insurance company, the large home financing giants, and money market mutual funds. In other words, the US authorities saved the creditors of major financial institutions from substantial losses, even though these institutions did not enjoy explicit insurance and, in many cases, the government had repeatedly emphasized that it would not save the creditors of those institutions.

But the increase in moral hazard is not just related to the decisions that were made under emergency conditions during the critical days of the crisis. Dodd-Frank and its implementation have brought other changes. For example, the FSOC has provided supervisory and regulatory oversight over all institutions deemed systemically important. Though the details are still in flux, this seems to involve all but small banks, as well as many broker-dealers, large assets managers, and potentially large hedge funds and other institutions not typically under the auspices of official supervision.

The economics of moral hazard raises concerns that expanding the power and perimeter of supervisory and regulatory agencies will reduce the incentives of private investors to monitor and discipline financial institutions. As official supervisory and regulatory agencies take on more responsibility for monitoring financial institutions and markets, private investors may take on less responsibility. As the government increases both implicit and explicit commitments to bail out private investors that make investment decisions based on official assessments of regulatory and supervisory agencies, private markets may reduce their own due diligence and monitoring. As official supervisory and regulatory agencies signal that they are responsible for systemically important financial institutions, private investors may naturally reduce the degree to which they expend resources disciplining such entities. 
US authorities have dramatically increased the TBTF problem. They have increased it by signaling that they will rescue failing institutions. And they have increased it by signaling that they are now responsible for a broader array of institutions. In empowering supervisory and regulation agencies and granting them authority over a wider array of activities, the US has discouraged market discipline.

\subsection{Has Regulatory Performance Improved?}

As bad as the crisis was, it would at least be a consolation if the approach to bank regulation had been strengthened, thereby reducing the likelihood of a serious crisis in the future. Unfortunately, it is difficult to make the case that this is so. To be sure, there have been some moves in the direction of tighter regulation. The Basel committee agreed to a 3 percent minimum (unweighted) leverage ratio, and an additional 2 percent (for a total of 5 percent of assets) for those institutions deemed to be systemically important financial institutions, or SIFIs; US regulators went a bit further and agreed that a SIFI has to meet a 6 percent minimum leverage ratio to be considered well capitalized, though these rules do not take effect until January 2018. US authorities also have moved to adopt a somewhat more stringent liquidity coverage ratio for larger banks, and to implement it two years in advance of the 2019 date agreed by the Basel committee. These changes are aimed at what most observers agree is an even greater problem after the crisis, the TBTF problem alluded to above. ${ }^{7}$ However, it is difficult to find observers outside the regulatory agencies who believe that these changes are anywhere near sufficient. By retaining risk weights for minimum capital ratios, they continue the problem noted above of encouraging banks to hold similar portfolios. Moreover, the Basel committee's response to concerns about increasing complexity of regulation was to form a (nother) subcommittee to study the issue; their report asserts the need to achieve simplicity while retaining risk weighting (Caprio, 2013).

This most disturbing sign regarding regulatory performance has been the general failure to recognize the problems of regulatory bias, and indeed the signs that this bias in favor of banks continues.

\footnotetext{
${ }^{7}$ For a further discussion, see Barth and Prabha (2014) and Barth et al. (2012) and the references cited therein.
} 
For example, neither the Federal Reserve nor OCC examiners were aware of the risks that were being run by Morgan's 'London Whale', until after the fact, and do not seem to have been close to detecting its activities in advance. US and UK regulators ignored the Libor manipulation by a group of large banks until it became a major scandal. As reported, Federal Reserve and BOE officials were aware of the activity for some time yet refrained from taking any actions. ${ }^{8}$ Subsequent regulatory action since then could be interpreted as a change in regulatory bias but, more convincingly, is an argument in favor of regulatory oversight; rather than being accountable only in the cases when information happens to become public, regulators regularly should be subject to review. The Iran money-laundering scandal was broken by the New York banking superintendent; even though the Federal Reserve licensed Standard Chartered, which clearly was breaking a US federal law, it is remarkable that it took a state regulatory body to bring the case forward. Federal Reserve officials look to have been at the least underperforming in their jobs or, at worst, looking the other way in favor of a bank they were overseeing. The dramatic dearth of bankers who have been prosecuted for fraud, in sharp contrast to the S\&L crisis, underlines the impression that government is biased in favors of bankers.

Regulators' proclivity to act in the interest of the regulatees was amply in evidence when they wrote one of the implementing rules for Dodd-Frank, which requires banks to maintain at least $5 \%$ of the loans that they were selling. As noted earlier, federal regulators allowed exemptions so broad that the requirement would mostly be irrelevant. ${ }^{9}$ Even more worrisome and also right up to the present, regulators have been playing along with banks' practice of maintaining second mortgages at face value on their books, even when borrowers were delinquent. As Yves Smith has pointed out, by not forcing banks to write down home equity loans (many of which were still on the originating banks' books), and even allowing banks to add unpaid interest to mortgage balances, regulators contributed to the drawing out of the mortgage crisis. ${ }^{10}$ This unwillingness to act in the interest of the public rather than in the interests of

\footnotetext{
${ }^{8}$ See Merced and Protess (2012).

${ }^{9}$ See Zibel and Timiraos (2013) and also Kwak (2013).

${ }^{10}$ See Smith (2013) and the Reuters article cited therein.
} 
the banks is similar to the Federal Reserve's inaction in 2004 when given an FBI report about widespread mortgage fraud.

To be sure, regulators do not always take decisions that support the banks. For example, the Federal Reserve was perceived to have been tough on the latest round of stress tests, denying Citi's request to buy back shares. However, the argument that regulators are biased in favor of the 'home team,' meaning the banks, is similar to that argument in sports—-no one asserts that the referees or umpires (at least in those sports without some form of instant replay) make every call in favor of the home team, only enough calls that help home teams win more games than they lose. And the fact that the same 'tough' stress tests missed the $\$ 4$ billion mistake on Bank of America's balance sheet, uncovered shortly thereafter, supports this view. ${ }^{11}$ Also, the fines that have been levied against major banks increased in the last year, but they are perceived very much as a cost of doing business; when Morgan's record fine was announced, its stock price rose. Thus, although it is fair to say that there have been some modest signs of regulatory toughening since the crisis began, it is hard to believe that regulators' bias in favor of banks has changed significantly enough.

\section{Conclusions}

The perfect storm explanation of the global financial crisis is a perfect excuse for regulators: no one could have anticipated it; thus no one can be blamed. This faulty diagnosis of the crisis - the lack of attention to a central factor, regulatory inaction — paved the way for the response, namely one of an increasingly complex regulatory framework in the United States (Dodd-Frank) and industrial countries more broadly (Basel III). Indeed, one of the curious features of the crisis is that the Federal Reserve, whose regulatory inaction contributed to the crisis, nonetheless was rewarded with a larger role in safeguarding systemic stability; its loss of the consumer protection function seems to have been without any lament. And the Basel approach to bank regulation, which featured reliance either on ratings or risk

\footnotetext{
${ }^{11}$ See Eavis and Corkery (2014).
} 
models, both of which failed in the run-up to the crisis, now features more of the same, with a bit higher capital requirements and a complex liquidity rule.

Evidence that economies are better protected from crises is hard to find: concentration in the banking system has increased, leading to more concern about TBTF banks, and there is scant evidence that regulators are any more accountable. The sole mechanism to increase regulatory accountability, the Financial Stability Oversight Council, amounts to regulators getting together to give themselves a grade; if this approach were thought to be effective in producing accurate assessments of performance, it is a wonder the universities do not employ it, given most professors' antipathy to the grading process. The interagency financial regulatory group in existence since the late 1970s oversaw the savings and loan (S\&L) crisis and the global financial crisis, hardly a record to inspire confidence. And with more complex regulation and no attention to regulatory disclosure, regulators in practice are less accountable than in the past. In fact, increased complexity essentially puts the regulatory experts, who failed in the last crisis, in a more dominant position.

Given that regulatory inaction was an important factor in the crisis, finding a way to get regulators to use their tools in the public interest is the central problem of bank regulation, and one that is not being addressed. Increased accountability needs to be part of the solution, but true regulatory accountability means not just more information about what regulators are doing. It also means more informed discussion of their actions and inaction. We have proposed previously (Barth et al., 2012) the creation of an agency that would have access to all of the information available to regulators and whose sole function would be to publish a regular report on the key systemic risks in the financial system and an assessment of the adequacy of regulators' responses, or lack thereof. We have also acknowledged the difficulty with implementing this proposal, but we see no alternative that would credibly reduce regulatory bias. Indeed, we fear that turning over so much control to unaccountable technocrats is incompatible with democracy, in addition to doing little to improve the safety and soundness of the financial system. 


\section{References}

Barth, J.R. and Prabha, A. (2013), 'Breaking (Banks) Up Is Hard to Do: New Perspective on Too Big to Fail’, working paper, Milken Institute, LA, 6 March.

Barth, J.R., Prabha, A. and Swagel, P. (2012), 'Just How Big Is the Too Big to Fail Problem', Journal of Banking Regulation, Vol. 13, pp. 265-99.

Barth, J.R., Caprio, G. and Levine, R. (2012), Guardians of Finance: Making Regulators Work for Us, The MIT Press, Cambridge, MA.

Barth, J.R., Li, T., Lu, W., Phumiwasana, T. and Yago, G. (2009), The Rise and Fall of the US Mortgage and Credit Markets, John Wiley\& Sons, Hoboken, NJ.

Caprio, G. (2013), 'Financial Regulation After the Crisis: How Did We Get Here, and How to Get Out', in Asia Economic Policy Conference in San Francisco Federal Reserve Bank, 2013, London School of Economics Financial Markets Group Special Paper 226, November 2013.

Danielsson, J., Embrechts, P., Goodhart, C., Keating, C., Muennich, F., Renault, O. and Shin, H.S. (2001), 'An Academic Response to Basel II', London School of Economics Financial Markets Group, Special Paper 130, May 2001.

Eavis, P. and Corkery, M. (2014), 'Bank of America Finds a Mistake: \$4 Billion Less Capital', available at: http://dealbook.nytimes.com/2014/04/28/bank-of-america-suspends-buyback-and-dividend-increase/ (accessed 18 July 2014).

Haldane, A.G. and Madouros, V. (2012), 'The Dog and the Frisbee', available at: http://www.bis.org/review/r120905a.pdf (accessed 18 July 2014).

Kwak, J. (2013), 'Regulators Repeat Exactly What They Did During the Last Housing Boom', available at: http://baselinescenario.com/2013/08/28/regulators-repeat-exactly-what-they-did-during-the-lasthousing-

boom/?utm_source=feedburner\&utm_medium=email\&utm_campaign=Feed $\% 3 \mathrm{~A}+$ BaselineScenario+\% 2 8The+Baseline+Scenario\%29 (accessed 18 July 2014).

Levitin, A.J. (2014), 'The Politics of Financial Regulation and the Regulation of Financial Politics: A Review Essay’, Harvard Law Review, Vol. 127, pp. 1991-2068.

Lewis, M. (2009), 'The Man Who Crashed the World', available at:

http://haraldhau.com/The_Man_Who_Crashed_the_World.pdf (accessed 18 July 2014).

Levine, R. (2011), 'The Governance of Financial Regulation: Reform Lessons from the Recent Crisis', Special Issue in International Review of Finance, Vol. 12, Issue 1, pp. 39-56.

Labaton, S. (2008), 'Agency's '04 Rule Let Banks Pile Up New Debt', available at: http://www.nytimes.com/2008/10/03/business/03sec.html?pagewanted=1\&_r=2\&hp (accessed 18 July 2014).

McDonald, L.G. and Robinson, P. (2009), A Colossal Failure of Common Sense: The Inside Story of the Collapse of Lehman Brothers, Crown Publishing Company, New York, NY. 
Merced, M.D. and Protess, B. (2012), 'New York Federal Reserve Knew of False Barclays Reports on Rates', available at: http://dealbook.nytimes.com/2012/07/13/barclays-informed-new-york-Federal Reserve-of-problems-with-libor-in-2007/ (accessed 18 July 2014).

Rudegeair, P. (2013), 'Insight: A New Wave of U.S. Mortgage Trouble Threatens', available at: http://www.reuters.com/article/2013/11/26/us-usa-mortgages-homeequity-insightidUSBRE9AP05J20131126 (accessed 18 July 2014).

Smith, Y. (2013), 'Big Banks About to Start Booking Second Mortgage Losses They Can No Longer Extend and Pretend Away', available at: http://www.nakedcapitalism.com/2013/12/big-banks-about-tostart-booking-second-mortgage-losses-they-can-no-longer-extend-and-pretend-away.html (accessed 18 July 2014).

Tett, G. (2009), Fool's Gold: The Inside Story of J.P. Morgan and How Wall St. Greed Corrupted Its Bold Dream and Created a Financial Catastrophe, Free Press, New York, NY.

Wilmarth, A.E. (2013), 'Citigroup: A Case Study in Managerial and Regulatory Failures', available at: http://scholarship.law.gwu.edu/cgi/viewcontent.cgi?article=2234\&context=faculty_publications (accessed 18 July 2014).

Zibel, A. and Timiraos, N. (2013), 'Regulators Back Away From Tougher Mortgage Rules: A Win for Housing Lobby, But Critics Warn of Toxic Loans', available at: http://online.wsj.com/news/articles/SB10001424127887324324404579041040433133698?mg=reno64wsjl (accessed 18 July 2014). 